\title{
THE RELATION OF THE CARBOHYDRATE-SPLITTING FERMENTS TO THE SOLUBLE TOXINS OF DIPHTHERIA BACILLI*
}

\author{
Joh A. Kolmer and EMILy L. Moshage \\ From the Laboratory of the Philadelphia Hospital for Contagious Diseases, Philadelphia
}

Of considerable interest and importance is the possible relationship of the soluble toxins of which diphtheria toxin is a type, to the true enzymes, or unorganized soluble ferments, elaborated by the vegetable cell, the activity of which is entirely independent of any of the life processes of the cell. There are several points of resemblance between the soluble toxins on one hand and the ferments, or enzymes, on the other. Both are products of the metabolism of living cells; both exhibit a latent period before manifesting their individual activities; both substances represent a method or means by which the organism attempts to modify its environment so as to render the surroundings suitable for its nutrition and growth: both show a strong affinity for their substrata; and first manifest their activity by combining with them; the activities of both seem to depend largely on the temperature to which they are exposed and both are usually affected by temperatures above $70 \mathrm{C}$.

The two great differences, however, between toxins and enzymes are the greater activity of the latter-even minute amounts of an enzyme having the power to split up or decompose large quantities of complex organic compounds, whereas when a toxin unites with a substance it loses its identity, and in its activity follows the law of multiple proportions-and the fact that antitoxins may be produced in large amounts whereas the production of antibodies to the enzymes, the true antiferments, is sharply limited.

It is well established that virulent diphtheria bacilli are invariably capable of splitting some carbohydrate, notably dextrose and dextrin, and it is also well proved that certain types of nonvirulent bacilli, notably Bacillus hofmanni, are unable to ferment any of the common carbohydrates, but between these opposite types may be found a large number of diphtheria bacilli apparently nonvirulent yet capable of fermenting certain carbohydrates in a rapid and characteristic manner.

* Received for publication December 10, 1915. 
In other words, while we have never encountered a culture of diphtheria bacilli virulent for guinea-pigs that was totally without power of splitting some carbohydrate, we frequently have come upon cultures capable of exerting this ferment activity that were nonvirulent for guinea-pigs.

It would appear, therefore, that generally those bacilli capable o producing demonstrable amounts of soluble toxin, also produce carbo hydrate-splitting ferments. Is there a possible relationship between the toxin and the carbohydrate-splitting process? Does the toxin itseli behave as a ferment capable of acting on carbohydrates or is it entirely separate from and independent of these ferments?

We have studied these questions experimentally (1) by testing the carbohydrate-splitting powers of several potent bacteria-free diphtheria toxins; and (2) by cultivating virulent carbohydrate-splitting diphtheria bacilli in the presence of an excess of sterile preservative-free antitoxin in order to neutralize, as it were, the nascent toxin as quickly as produced. The results of our experiments support the view that diphtheria toxin itself apparently takes no part in the fermentation of carbohydrates, that soluble toxin and the carbohydrate-splitting ferments are separate secretory products of certain types of diphtheria bacilli.

\section{EXPERIMENTS WITH BACTERIA-FREE TOXINS}

The ferment activity of three different lots of filtered sterile diphtheria toxin was tested separately with dextrose, dextcrin, and, in the case of Toxin 1, lactose-1\% of each-in Hiss serum-water media.

Toxin 1 (obtained from Dr. A. P. Hitchens and Dr. C. P. Brown, Glenolden, $\mathrm{Pa}$.) had been prepared about 2 months previously and preserved in the refrigerator with $0.5 \%$ tricresol. The $\mathrm{L}+$ dose was 0.82 c.c.

Toxin 2 (obtained from Dr. C. Y. White) had been prepared from the Park-Williams bacillus No. 8 and contained $0.4 \%$ tricresol. The M. L. D. was 0.01 c.c. In order to exclude any inhibitory influence of the preservative upon the possible carbohydrate-splitting properties of a soluble toxin, a freshly prepared product free of germicide or preservative was tested, but with negative results. The culture itself. however, fermented several carbohydrates, such as dextrin. galactose, and levulose, vigorously.

Toxin 3 was prepared by growing the Park-Wrilliams bacillus No. 8 in broth for 5 days and filtering the living culture through a sterile 
Berkefeld filter. The toxin was used at once. The M. L. D. was 0.03 c.c.

The technic of these experiments consisted in placing these sterile toxins, in amounts ranging from 0.1 c.c. to 2 c.c., into a series of sterile test tubes, adding sufficient of the Hiss medium to make the total volume in each tube about 5 c.c., and incubating the tubes for at least 6 days at $37 \mathrm{C}$. In no instance after $1,2,3,4,5$, and 6 days was acidproduction found to have occurred. (One toxin contaminated with a staphylococcus, which produced changes in the various media, is excluded in this report.)

\section{EXPERIMENTS WITH NEUTRALIZED CULTURES}

A number of cultures of virulent diphtheria bacilli were cultivated in Hiss media in the presence of increasing amounts of diphtheria antitoxin designed to neutralize the toxin as quickly as produced by the bacilli, and acid-production studied with several carbohydrates. In this manner a further study was made of the possible relation of the soluble toxins to the processes of carbohydrate-fermentation.

The bacilli, which had been isolated from diphtheria patients, were of the granular varieties. Each was virulent for 300-gram guinea-pigs within a period of 3 days following subcutaneous injection of 1.5 c.c. of 3 -day broth cultures.

A fresh antitoxin serum, free of preservative, was used. Subsequent titration of this serum showed that it contained from 1,000 to 1,100 units of antitoxin per cubic centimeter. This serum was diluted with sterile plain neutral broth $1: 100,1: 10$, and $1: 5$, and 2 c.c. of each dilution were placed in test tubes with 2 c.c. of Hiss serum-water medium containing $1 \%$ of a carbohydrate and colored with litmus. After the addition of these dilutions, the test tubes finally contained about 20,200 , and 400 units of antitoxin, respectively, and after adding 2 c.c. of undiluted antitoxin to 2 c.c. of the Hiss medium the 4 th test tube contained 2,000 units, all in a total volume of 4 c.c.

All tubes were now inoculated with 0.1 c.c. of a 3-day broth culture of the diphtheria bacillus under study, and incubated at $37 \mathrm{C}$. for 4 or 5 days. Daily inspections were made and changes in the medium recorded.

After 5 days each tube of the series was examined for the presence of diphtheria bacilli and for purity of growth. (In every experiment the antitoxin dilutions were tested for sterility by culturing 2 c.c. of each in broth, and in all instances were found sterile.) After 4 or 5 days' incubation several cultures of each series were tested for free toxin by subcutaneously injecting 300 -gram guinea-pigs with 1.5 c.c. of the growth from the antitoxin Hiss serum-water medium.

Table 1 shows this method of procedure in one experiment, with the results, which were fairly typical of all experiments. 
TABLE 1

Culture 7*

\begin{tabular}{|c|c|c|c|c|c|c|c|c|c|}
\hline \multirow{2}{*}{ Tube } & \multirow{2}{*}{$\begin{array}{c}\text { Hiss } \\
\text { Serum } \\
\text { Water } \\
\text { Medium } \\
\text { 2 c.c. }\end{array}$} & \multirow{2}{*}{$\begin{array}{c}\text { Units } \\
\text { of } \\
\text { Anti- } \\
\text { toxin } \\
\text { Added }\end{array}$} & \multicolumn{5}{|c|}{ Results } & \multirow{2}{*}{$\begin{array}{c}\text { Examination } \\
\text { of } \\
\text { Culture } \\
\text { After } \\
5 \text { Da. }\end{array}$} & \multirow{2}{*}{$\begin{array}{l}\text { Guinea. } \\
\text { pig } \\
\text { Inocu- } \\
\text { lation } \\
\text { Test }\end{array}$} \\
\hline & & & $1 \mathrm{Da}$. & 2 Da. & 3 Da. & $4 \mathrm{Da}$. & $5 \mathrm{Da}$. & & \\
\hline $\begin{array}{r}1 \\
2 \\
3 \\
4 \\
5 \\
6 \\
7 \\
8 \\
9 \\
9 \\
10\end{array}$ & $\begin{array}{l}\text { Dextrose } \\
\text { Dextrose } \\
\text { Dextrose } \\
\text { Dextrose } \\
\text { Dextrin } \\
\text { Dextrin } \\
\text { Dextrin } \\
\text { Dextrin } \\
\text { Broth } \\
\text { Broth }\end{array}$ & $\begin{array}{r}20 \\
200 \\
400 \\
2000 \\
20 \\
200 \\
400 \\
2000 \\
20 \\
400\end{array}$ & Acid & $\begin{array}{c}\cdots \\
0 \\
0\end{array}$ & $\begin{array}{l}\text { Acid } \\
\text { Ooagu- } \\
\text { lation }\end{array}$ & $\begin{array}{l}\text { Acid } \\
\text { Coagu- } \\
\text { lation }\end{array}$ & $\begin{array}{l}\text { Acid } \\
\text { Coagu- } \\
\text { lation }\end{array}$ & $\begin{array}{l}\text { Pure, good } \\
\text { Pure, good } \\
\text { Pure, good } \\
\text { Few baeilli } \\
\text { Pure, good } \\
\text { Pure, good } \\
\text { Pure, good } \\
\text { Pew bacilli } \\
\text { Sternle } \\
\text { Sterile }\end{array}$ & $\begin{array}{l}\text { Negative } \\
\text { Negative } \\
\text { Negative } \\
\text { Negative } \\
\text { Negative } \\
0 \\
\text { Native } \\
\text { Negative } \\
0 \\
0 \\
0\end{array}$ \\
\hline
\end{tabular}

* Isolated from the throat of a diphtheria convalescent. Granular, Type C. One and five-tenths cuble centimeters of a 3 -day broth culture were fatal for a 300 -gram guinea-pig in 3 days. Tubes of culture medium and antitoxin were inoeulated with 0.1 c.c. of a 3-day broth culture.

Similar experiments were conducted with 6 other cultures, with almost identical results. Three cultures produced small amounts of acid in the presence of 2000 units of antitoxin after 3, 5, and 8 days respectively.

Our results show that the fermentation of these carbohydrates was in no way inhibited by the fact that the soluble toxins were neutralized as quickly as produced. In all instances the quantity of antitoxin added was sufficient to effect complete neutralization of the toxin. as determined by guinea-pig inoculation. When 2000 units of antitoxin were used, the growths of bacilli were relatively scant and we attribute the absence of fermentation within the 5-day limit in these tubes to the inhibitory influence of the serum on the growth of the bacilli.

That sufficient antitoxin to neutralize all toxin produced persisted in the Hiss serum-water-sugar cultures after an exposure to $37 \mathrm{C}$., was shown not only by the negative results of inoculation tests after 5 days, but also in another series of experiments, in which on separate occasions 3 virulent cultures of diphtheria bacilli were cultivated in Hiss serum-water-glucose medium in the presence of 100 units of sterile antitoxin, filtered through porcelain as soon as well-pronounced acidproduction had occurred-usually about the second day-and 2 c.c. and 4 c.c. of the filtrate injected subcutaneously into guinea-pigs weighing 250 to $300 \mathrm{gm}$. The results of these animal tests were completely negative, the animals showing no edema or toxemia. Further than this the filtrate contained sufficient antitoxin to protect guinea-pigs against fatal doses of diphtheria toxin. 
It would appear, therefore, that soluble diphtheria toxin takes no part in the fermentation of carbohydrates, this action being due to separate secretory products, or enzymes, of diphtheria bacilli.

Carbohydrate-fermentation in vitro by diphtheria bacilli does not run parallel with, or depend on, the vegetative vitality of the bacillus, that is, on its ability to survive and grow on artificial culture media, for pseudodiphtheria bacilli, as B. hofmanni, grow luxuriantly and yet are characterized by their lack of fermentative power for carbohydrates.

Acid-production by diphtheria bacilli, however, does run somewhat parallel to toxin-production and the degree of virulence. We have not so far found a culture both virulent for guinea-pigs and totally lacking in the power of fermenting some carbohydrate, whereas cultures totally unable to bring about fermentation have been found rather generally nonvirulent for animals. On the other hand, cultures of diphtheria bacilli nonvirulent for animals may be capable of splitting carbohydrates.

\section{CONCLUSION}

Carbohydrate-fermentation by diphtheria bacilli is dependent on secretory enzymic products of the diphtheria bacillus, but is independent of the soluble poison or toxin; these ferment-like carbohydrate-splitting products are most likely to be produced by toxin-producing bacilli. 